Short communication

\title{
Nitric oxide synthase-dependent immune response against gram negative bacteria in a crustacean, Litopenaeus vannamei
}

\author{
Tania Rodríguez-Ramos ${ }^{\mathrm{a}, 1}$, Yamila Carpio ${ }^{\mathrm{b}, 1}$, Jorge Bolívar ${ }^{\mathrm{c}}$, Leonardo Gómez ${ }^{\mathrm{b}}$, \\ Mario Pablo Estrada ${ }^{\text {b, * }}$, Carlos Pendón ${ }^{\text {c, ** }}$ \\ ${ }^{a}$ Center for Marine Research, University of Havana (CIM-UH), Cuba \\ ${ }^{\mathrm{b}}$ Center for Genetic Engeneering and Biotechnology (CIGB), Cuba \\ ${ }^{\mathrm{c}}$ Departamento de Biomedicina, Biotecnología y Salud Pública, Faculty of Sciences, University of Cadiz (UCA), Spain
}

\section{A R T I C L E I N F O}

\section{Article history:}

Received 30 November 2015

Received in revised form

14 January 2016

Accepted 15 January 2016

Available online 19 January 2016

\section{Keywords:}

Aeromonas hydrophila

Invertebrate immunity

Nitric oxide synthase

Litopenaeus vannamei

NOS

\begin{abstract}
A B S T R A C T
Nitric oxide (NO) is a short-lived radical generated by nitric oxide synthases (NOS). NO is involved in a variety of functions in invertebrates, including host defense. In previous studies, we isolated and sequenced for the first time the NOS gene from hemocytes of Panulirus argus, demonstrating the inducibility of this enzyme by lipopolysaccharide in vitro e in vivo. Hyperimmune serum was obtained from rabbits immunized with a P. argus -NOS fragment of $31 \mathrm{kDa}$ produced in Escherichia coli, which specifically detected the recombinant polypeptide and the endogenous NOS from lobster hemocytes by western blotting and immunofluorescence. In the present work, we demonstrate that the hyperimmune serum obtained against $P$. argus NOS also recognizes Litopenaeus vannamei NOS in hemocytes by western blotting and immunofluorescence. Our data also show that while the hemolymph of $L$. vannamei has a strong antibacterial activity against the Gram negative bacteria Aeromonas hydrophila, the administration of the anti NOS serum reduce the natural bacterial clearance. These results strongly suggest that NOS is required for the shrimp immune defense toward Gram negative bacteria. Therefore, the monitoring of induction of NOS could be an important tool for testing immunity in shrimp farming.
\end{abstract}

(ङ) 2016 Elsevier Ltd. All rights reserved.

\section{Introduction}

Nowadays, many crustacean species are being commercially exploited around the world, and specially decapods. Research into the immune system of these species may provide new insights into the management and control of diseases in natural and artificial environments. Nitric oxide (NO) is a key molecule produced in the innate immune systems of many species for antimicrobial defense. However, how NO production is regulated during bacterial infection in invertebrates, especially crustaceans, remains poorly understood. Nitric oxide is produced by nitric oxide synthases (NOS), a group of evolutionarily conserved cytosolic or membrane bound isoenzymes that convert the amino acid L-arginine to citrulline and $\mathrm{NO}$, which is oxidized into nonvolatile stable products, nitrite $\left(\mathrm{NO}_{2}^{-}\right)$ and nitrate $\left(\mathrm{NO}_{3}^{-}\right)$. In mammals, three isoforms of NOS have been

\footnotetext{
* Corresponding author.

** Corresponding author

E-mail addresses: mario.pablo@cigb.edu.cu (M.P. Estrada), carlos.pendon@uca.es (C. Pendón).

${ }^{1}$ Both authors contribute equally to this work.
}

identified. Two of these are constitutively expressed, mainly in the brain (nNOS) and endothelial cells (eNOS) and they are $\mathrm{Ca}^{2+}$ calmodulin dependent. A third enzyme, the inducible $\mathrm{Ca}^{2+}$-independent isoform (iNOS), is expressed in some cell types after stimulation with Escherichia coli lipopolysaccharide (LPS) and/or different cytokines such as interferon- $\gamma$, interleukin-1 $\beta$, or tumor necrosis factor- $\alpha[1,2]$. On the contrary, only one NOS gene has been reported in most invertebrate genomes. The three vertebrate NOS isozymes are presumed to have descended from a single ancestral gene in the course of invertebrate evolution [3].

The insights of the NOS/NO response in crustaceans upon PAMPs (pathogen-associated molecular patterns) challenge are still unclear. For example, while in Panulirus argus E. coli lipopolysaccharide (LPS) treatment stimulated both NO production and NOS mRNA in hemocytes [4,5], LPS treatment apparently increased NO production [6,7] but not NOS mRNA expression [6] in the hemocytes of Penaeus monodon. Moreover, although the cDNA sequences of NOS have been cloned in several shrimp species including Marsupenaeus japonicus [8], Litopenaeus vannamei [9], and Penaeus monodon [6], direct demonstration that NOS transcription or 
activity is correlated with bacterial clearance is virtually nonexistent except for one recent report which demonstrated that endogenous NO produced by $L$. vannamei hepatopancreatic cells occurs in enzymatic regulated manners and it is sufficient to act as a bactericidal molecule for Vibrio harveyi clearance [10].

In previous studies, we isolated and sequenced for the first time the NOS gene from hemocytes of $P$. argus [4]. Hyperimmune serum (anti Pa $31 \mathrm{kDa}-\mathrm{NOS}$ ) was obtained from rabbits immunized with a polypeptide of $31 \mathrm{kDa}$ from $P$. argus NOS ( $\mathrm{Pa} 31 \mathrm{kDa}-\mathrm{NOS}$ ) produced in $E$. coli, which specifically detected the recombinant polypeptide and the endogenous NOS from lobster hemocytes by western blotting and immunofluorescence [5]. In this study, after demonstrating the recognition of $L$. vannamei NOS by anti Pa 31 kDa-NOS, we focused on the antimicrobial effect of NOS against the Gram negative bacteria Aeromonas hydrophila infection in the hemolymph of L. vannamei.

\section{Material and methods}

\subsection{Experimental animals and bacterial strain}

Sexually immature, healthy Pacific white shrimps (L. vannamei) between 8 and $10 \mathrm{~g}$ of weight were provided by the Yaguacan Hatchery (Cienfuegos, Cuba) and were kept in aerated seawater (35 mg/L), with controlled photoperiod of 12:12 h light:darkness until use. All experiments were performed after one week in these conditions. Experimental animals were treated according with the European Union Directive (EEC, 1986) for the protection of animals used for experimental and other scientific purposes. A. hydrophila used in this study was previously isolated from diseased shrimps in our laboratory.

\subsection{Hemolymph collection}

Hemolymph for the different assays was collected through the ventral sinus using a pyrogen-free disposable syringe containing the same volume of pre-cooled anticoagulant solution. A modified Citrate-EDTA buffer ( $400 \mathrm{mM} \mathrm{NaCl}, 0.1 \mathrm{M}$ glucose, $30 \mathrm{mM}$ trisodium citrate, $26 \mathrm{mM}$ citric acid and $20 \mathrm{mM}$ EDTA, pH 4.6) was used as anticoagulant [11].

For hemocyte collection, the mixture was centrifuged at $700 \mathrm{~g}$ for $10 \mathrm{~min}$ at $4{ }^{\circ} \mathrm{C}$. The cell pellet was washed twice with anticoagulant and suspended again in anticoagulant solution for western blotting and immunohistochemistry assays. For the antibacterial assays $20 \mu \mathrm{L}$ of the total hemolymph was kept in individual tubes before centrifugation.

\subsection{Immunodetection of native NOS in hemocytes by western blotting}

Polypeptides from hemocytes were extracted using the following solution: $400 \mathrm{mM} \mathrm{NaCl}, 10 \mathrm{mM} \mathrm{KCl}$ and Triton 1\%, $\mathrm{pH} 7.0$. Samples were resolved in 10\% SDS-PAGE under non-reducing conditions (1\% glycerol, 0.4\% SDS, $12.5 \mathrm{mM}$ Tris- $\mathrm{HCl}, \mathrm{pH} 6.6$ ) and were electrotransferred overnight onto nitrocellulose membranes (Amersham) using a TransBlot ${ }^{\mathrm{TM}}$ transfer (BioRad). The membrane was blocked for $2 \mathrm{~h}$ with 5\% skimmed milk (Oxoid), incubated overnight with the anti $\mathrm{Pa} 31 \mathrm{kDa}-\mathrm{NOS}$ serum previously obtained by us [5] diluted $1: 10000$ in PBS ( $137 \mathrm{mM} \mathrm{NaCl}, 2.7 \mathrm{mM} \mathrm{KCl}, 4.3 \mathrm{mM}$ $\mathrm{Na}_{2} \mathrm{HPO}_{4} 7 \mathrm{H}_{2} \mathrm{O}, \mathrm{pH} 7.3$ ) and washed with PBST (PBS plus $0.05 \%$ Tween 20) three times for $30 \mathrm{~min}$. Afterward, the membrane was incubated with a goat anti-rabbit IgG-horseradish peroxidase conjugate (Amersham) for $1 \mathrm{~h}$, subsequently washed, and the enhanced chemiluminescence detection system (Amersham Biosciences) was used for visualization of protein bands.

\subsection{Purification of IgG specific against P. argus NOS}

Total IgG specific for P. argus NOS was purified following the protocol described by Gómez et al. [12]. Briefly, the Sepharose CL4B (Amersham-Pharmacia) was moderately activated (6-12 $\mu \mathrm{mol} / \mathrm{ml}$ ) of cyanate esters with Cyanogen bromide (Merck) according to the Wilcheck classification using a modified procedure already described by Axen [13,14]. A modified Koenig reaction determination of cyanate ester concentration on the support was made [15]. The CNBr activated Sepharose CL-4B matrix was wetted in $1 \mathrm{mM} \mathrm{HCL}$ for $15 \mathrm{~min}$, and washings with $0.1 \mathrm{M} \mathrm{Na}_{2} \mathrm{CO}_{3} / 0.1 \mathrm{M}$ $\mathrm{NaHCO}_{3}-0.5 \mathrm{M} \mathrm{NaCL}$ pH 8.3 were performed. The recombinant $31 \mathrm{kDa} P a-N O S$ was coupled by covalent bonds on the support at $\mathrm{pH}$ 8.3 during $2 \mathrm{~h}$ at $25^{\circ} \mathrm{C}$ by gentle stirring. Then, $0.1 \mathrm{M}$ glycine $\mathrm{pH} 8.0$ was added to block free reactive groups and five alternate washings with $0.1 \mathrm{M} \mathrm{C}_{2} \mathrm{H}_{3} \mathrm{O}_{2} \mathrm{Na} / 0.5 \mathrm{M} \mathrm{NaCL} \mathrm{pH} 4.0$ and $0.1 \mathrm{M} \mathrm{Na}_{2} \mathrm{CO}_{3} / 0.1 \mathrm{M}$ $\mathrm{NaHCO}_{3}-0.5 \mathrm{M} \mathrm{NaCL}$ pH 8.3 were made. Finally, the immunosorbents were washed and stored in PBS/0.01\% Tiomersal pH 7.2 at $4{ }^{\circ} \mathrm{C}$ until use [12].

The processes of antiserum binding and elution were made according to the protocol proposed by the European Molecular Biology Laboratory (http://www.embl.de). Briefly, after washing the beads 3 times with PBS in a $50 \mathrm{~mL}$ Corning tube, $1 \mathrm{~mL}$ of beads was resuspended with $10 \mathrm{~mL}$ of PBS and $10 \mathrm{~mL}$ of antiserum. The incubation was overnight at $4{ }^{\circ} \mathrm{C}$ on a tumbler. The elution of antibodies was performed at $4{ }^{\circ} \mathrm{C}$. First, the beads were washed 3 times with $50 \mathrm{~mL}$ of PBS and then resuspended in $10 \mathrm{~mL}$ of PBS. Then, the beads were loaded into a chromatography column where they were washed with PBS for approximately $1 \mathrm{~h}$ until OD $280=0$. To elute the bound antibodies, $200 \mathrm{mM}$ glycine $\mathrm{pH} 2.8$ were added to the column at $4{ }^{\circ} \mathrm{C}$ collecting $1 \mathrm{~mL}$ aliquots into tubes containing $27 \mu \mathrm{L}$ of $3 \mathrm{M}$ Tris $-\mathrm{HCl}, \mathrm{pH} 8.8$ and $100 \mu \mathrm{L}$ of $3 \mathrm{M} \mathrm{KCl}$. The OD 280 of fractions was measured and the antibodies solution was dialyzed at $4{ }^{\circ} \mathrm{C}$ against PBS overnight. Total proteins were quantified using the BCA Protein Assay Kit (Pierce) according to the manufacturer's instructions. Aliquots were kept at $-20{ }^{\circ} \mathrm{C}$ until use.

\subsection{Immunodetection of native NOS in hemocytes by immunofluorescence}

For indirect immunofluorescence staining, shrimp hemocytes were washed twice with anticoagulant and finally exposed in vitro to $0.5 \mathrm{mg} / \mathrm{mL}$ of $E$. coli LPS as previously described [5]. After $1 \mathrm{~h}$ the hemocytes were extended on poly-Lysine treated coverslips and then fixed in cold acetone for $10 \mathrm{~min}$. Cells were then washed with PBS, blocked with BSA $3 \%$ in PBS for 30 min and incubated with the primary antibody diluted in PBS (1:400 of purified anti-Pa $31 \mathrm{kDa}-$ NOS serum) at $37{ }^{\circ} \mathrm{C}$ for $75 \mathrm{~min}$. Cells were then washed with PBS for $30 \mathrm{~min}$ at room temperature and incubated with anti-rabbit Alexa fluor 488 labeled secondary antibody (Molecular Probes) at $37{ }^{\circ} \mathrm{C}$ for $45 \mathrm{~min}$. Finally, cells were washed twice in PBS and mounted in PBS-glycerol containing DAPI at $0.1 \mu \mathrm{g} / \mathrm{mL}$. A Zeiss Axiophot microscope equipped with a $63 \times$ NA 1.3 oil-immersion objective was routinely used. Images were taken with a SPOT Camera (Diagnostic Instruments Inc.) using the same settings, and processed with Adobe Photoshop CS6.

\subsection{In vitro and in vivo hemolymph antimicrobial assay}

For the in vitro hemolymph antimicrobial assay, A. hydrophila bacteria were grown in Tryptic Soy Broth. Briefly, logarithmic phase microorganism cultures were diluted in the broth to an estimated $\mathrm{OD}_{600}$ of 0.001 , which is approximately equivalent to $10^{5}$ colonyforming units (CFU)/mL. Diluted microorganism $(90 \mu \mathrm{L})$ was mixed with $10 \mu \mathrm{L}$ of medium (control) or the hemolymph in wells of a 
polypropylene microtiter plates (Greiner Bio-One). Hemolymph from 3 shrimps per treatment was assayed by duplicate. The samples were 2 -fold serially diluted. The growth was monitored, after an overnight incubation at $28{ }^{\circ} \mathrm{C}$, by measuring the change in the absorbance of the culture at $600 \mathrm{~nm}$ using a microplate reader.

For the in vivo assay, two doses of $A$. hydrophila were assayed: $1 \times 10^{5}$ and $1 \times 10^{7} \mathrm{CFU}$. Eight shrimp per dose were injected with $50 \mu \mathrm{L}$ solution of $A$. hydrophila or injection of saline solution alone as a negative control. Four individuals from each group were sampled at 5 and $24 \mathrm{~h}$ post injection (hpi) and $10 \mu \mathrm{L}$ of pure, 1:10 and 1:100 diluted hemolymphs were plated in Luria Bertani agar plates. Plates were incubated for $24 \mathrm{~h}$ at $28{ }^{\circ} \mathrm{C}$, and afterward the CFU were determined by counting.

\subsection{Effect of the immuno-neutralization of NOS on NOS activity in the hemolymph of L. vannamei}

Ten animals were distributed in two experimental groups of five animals per group. One group was injected with $50 \mu \mathrm{L}$ of preimmune serum previously obtained by us [5] and the other with the same volume of purified specific anti $P a 31 \mathrm{kDa}-N O S$ serum. The concentration of proteins of the purified NOS antiserum and the pre-immune serum were adjusted to be equivalent $(1.2 \mathrm{mg} / \mathrm{mL})$. After $5 \mathrm{~h}$ post-injection, hemolymph was extracted and plasma was used to measure nitrites as an indicator of NOS activity in vivo. To achieve this objective nitrates were first converted to nitrites using the nitrate reductase enzyme (Boehringer, Germany). Briefly, $50 \mu \mathrm{l}$ of samples were added to each well and mixed with $50 \mu$ of a freshly prepared reaction mixture containing nitrate reductase (2 U/mL) (Boehringer, UK), reduced nicotinamide adenine dinucleotide phosphate (NADPH: $0.344 \mathrm{mM}$ ) and flavine adenine dinucleotide (FAD: $0.044 \mathrm{mM}$ ) in phosphate buffer. Two fold serial dilutions of sodium nitrate $(250 \mu \mathrm{M})$ were used as standard curve. The plates were incubated at $37{ }^{\circ} \mathrm{C}$ for $1 \mathrm{~h}$. Total nitrite was determined adding $200 \mu \mathrm{l}$ of Griess reagents ( $1 \%$ sulphanilamide, $0.1 \%$ naphthylethylene diamine dihydrochloride, $\left.2.5 \% \mathrm{H}_{3} \mathrm{PO}_{4}\right)$. This method is based on the reaction of nitrites with Griess reagents, which generates a purple-azo dye product that can be monitored by a spectrophotometer at $540 \mathrm{~nm}$.

\subsection{Effect of the immuno-neutralization of NOS on the antibacterial activity of the hemolymph of L. vannamei}

For this experiment, four experimental groups and five animals per group were established. Shrimps were co-injected with $50 \mu \mathrm{L}$ containing $1 \times 10^{5} \mathrm{CFU}$ of $A$. hydrophila and $50 \mu \mathrm{l}$ of the respective treatment: Group 1: Negative control $450 \mathrm{mM} \mathrm{NaCl}$, Group 2: LNMMA $120 \mu \mathrm{g} / \mathrm{mL}$ (Sigma) ( $\mathrm{N}^{\mathrm{G}}$-Monomethyl-L-arginine, an inhibitor selective for mammalian cNOSs), Group 3: pre-immune serum, Group 4: purified anti Pa31 kDa-NOS serum. The concentration of proteins of the purified NOS antiserum and the pre-immune serum were adjusted to be equivalent $(1.2 \mathrm{mg} / \mathrm{mL})$. Animals were kept in $10 \mathrm{~L}$ of sea water with aeration. After $24 \mathrm{~h}$ post-injection, hemolymph were extracted and $10 \mu \mathrm{L}$ of pure, $1: 10$ and 1:100 diluted hemolymph were plated in Luria Bertani agar plates. Plates were incubated for $24 \mathrm{~h}$ at $28^{\circ} \mathrm{C}$. Afterward, the CFU was determined for each treatment. This experiment was performed in duplicate.

\subsection{Statistical analysis}

The statistical analysis was done using Graph Pad Software Inc. version 6 (San Diego, CA, USA).

\section{Results and discussion}

\subsection{Immunodetection of native NOS from L. vannamei cells by western blotting and immunofluorescence}

In order to detect the endogenous NOS from L. vannamei, homogenates of hemocytes were analyzed by SDS-PAGE under nonreducing conditions followed by western blotting. Consequently, a predominant band was obtained with the expected size of the shrimp NOS homodimer (Fig. 1A) according to the sequence reported by Yao et al. [9]. These authors reported a nucleotide
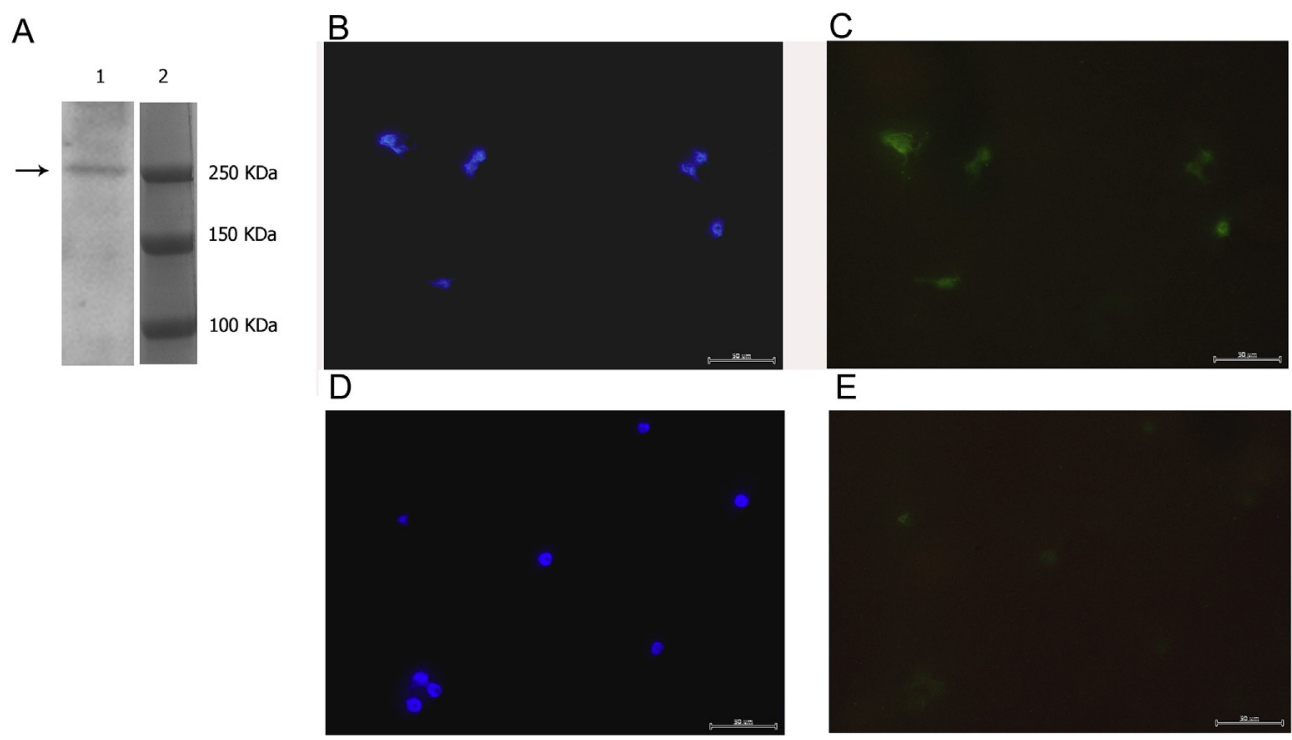

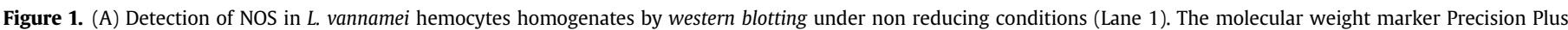

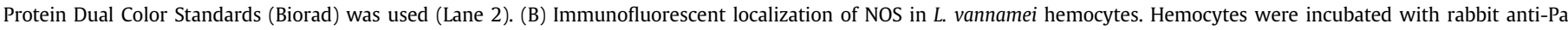

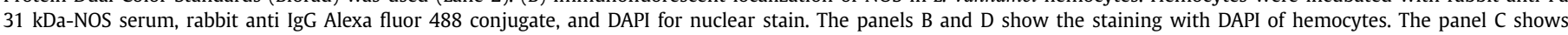

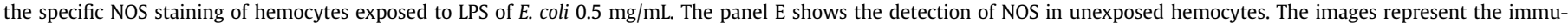

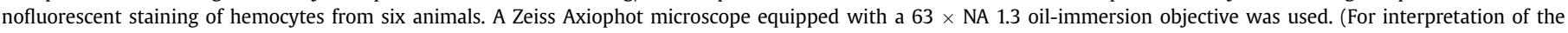
references to colour in this figure legend, the reader is referred to the web version of this article.) 
sequence contains an open reading frame of 3540 bp encoding a polypeptide of 1179 amino acids with theoretical molecular weight of $133 \mathrm{kDa}$. The result obtained in the western blotting demonstrated the capacity of the anti-Pa $31 \mathrm{kDa}-\mathrm{NOS}$ antibody obtained in lobster to detect NOS in shrimps allowing us its use in further experiments. Native NOS was also specifically recognized by the anti$\mathrm{Pa} 31 \mathrm{kDa}-\mathrm{NOS}$ antibody in the hemocytes using immunofluorescence microscopy. Despite that the results are qualitative; the intensity of the fluorescence seems to be higher in those cells exposed to E. coli LPS with respect to the unexposed hemocytes (Fig. 1B-E). Control hemocytes incubated with pre-immune serum showed no background fluorescence (data not shown). Similar results were obtained with hemocytes of the lobster P. regius [5], and again the treatment with LPS caused aggregation of cells and morphological changes, probably attributable to processes of cell degranulation. In addition to $P$. regius lobster and the results obtained herein, NOS has also been previously detected by immunostaining in Y-organ of the crab Gecarcinus lateralis [16] and Carcinus maenas [17] but using a universal NOS antibody. The increase in fluorescence intensity observed after LPS stimulation are in agreement with the previous finding in L. vannamei in which the levels of NOS transcripts sharply increased at 3-h post-injection, and were 8.8 times higher than in the control after injection with $50 \mu \mathrm{L}$ of $0.2 \mathrm{mg} / \mathrm{mL}$ LPS from $E$. coli. These authors suggested that the $L$. vannamei NOS in hemocytes may play an important role in shrimp defense against pathogen infection [9].

\subsection{In vitro and in vivo hemolymph antimicrobial assay}

It is widely known that shrimps have an innate immune response involving both cellular and humoral factors and one of the main groups of pathogens affecting shrimps is Gram negative bacteria, recognized by the host immune system because of the LPS located in the outer layer of the bacterial cell wall $[18,19]$. In this study, we performed both in vitro and in vivo experiments to demonstrate the bacterial hemolymph clearance capacity in shrimps, specifically against $A$. hydrophila (Fig. 2). In all cases, the results showed the strong antibacterial activity of the hemolymph. The dose of $1 \times 10^{5}$ CFU resulted in higher clearance percent at $5 \mathrm{~h}$ as compared to $1 \times 10^{7} \mathrm{CFU}(\mathrm{p}<0.05)$. However, the dose of $1 \times 10^{5} \mathrm{CFU}$ at $24 \mathrm{~h}$ was selected for further experiments because in these conditions the bacterial clearance reached $100 \%$ (Fig. 2B,C). Additionally, two shrimps died at $24 \mathrm{~h}$ with the dose of $1 \times 10^{7} \mathrm{CFU}$. Antibacterial activity has previously been described in the hemolymph and/or the hemocytes of a wide range of crustacean species [20-23]. There are several important factors reported to be involved in this antibacterial activity such as antimicrobial peptides, lectins, phenoloxidase and nitric oxide among others [24].

\subsection{Effect of the immuno-neutralization of NOS on its activity and the anti-bacterial activity of the hemolymph of L. vannamei}

Shrimps injected with the anti-Pa $31 \mathrm{kDa}-\mathrm{NOS}$ antibody showed lower NOS activity in the hemolymph after $5 \mathrm{~h}$ post injection as compared with shrimps injected with pre-immune serum $(\mathrm{p}<0.05)$ (Fig 3A). These results showed the capacity of the anti-Pa $31 \mathrm{kDa}-\mathrm{NOS}$ antibody to neutralize NOS activity in shrimps. After this information was obtained, shrimps were exposed in vivo to the Gram negative bacteria $A$. hydrophila to finally demonstrate the effect of the immunoneutralization of NOS on the bacterial clearance in the hemolymph. As a result, we obtained that after $24 \mathrm{~h}$ of injection with of $1 \times 10^{5} \mathrm{CFU}$ of bacteria, the plates with hemolymph from shrimps injected with saline solution or pre immune serum did not show any bacterial growth (Fig. 3 B, C, D), while

A

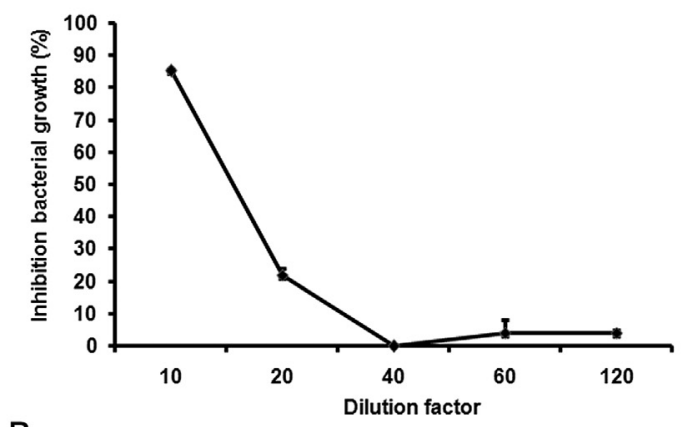

C

B
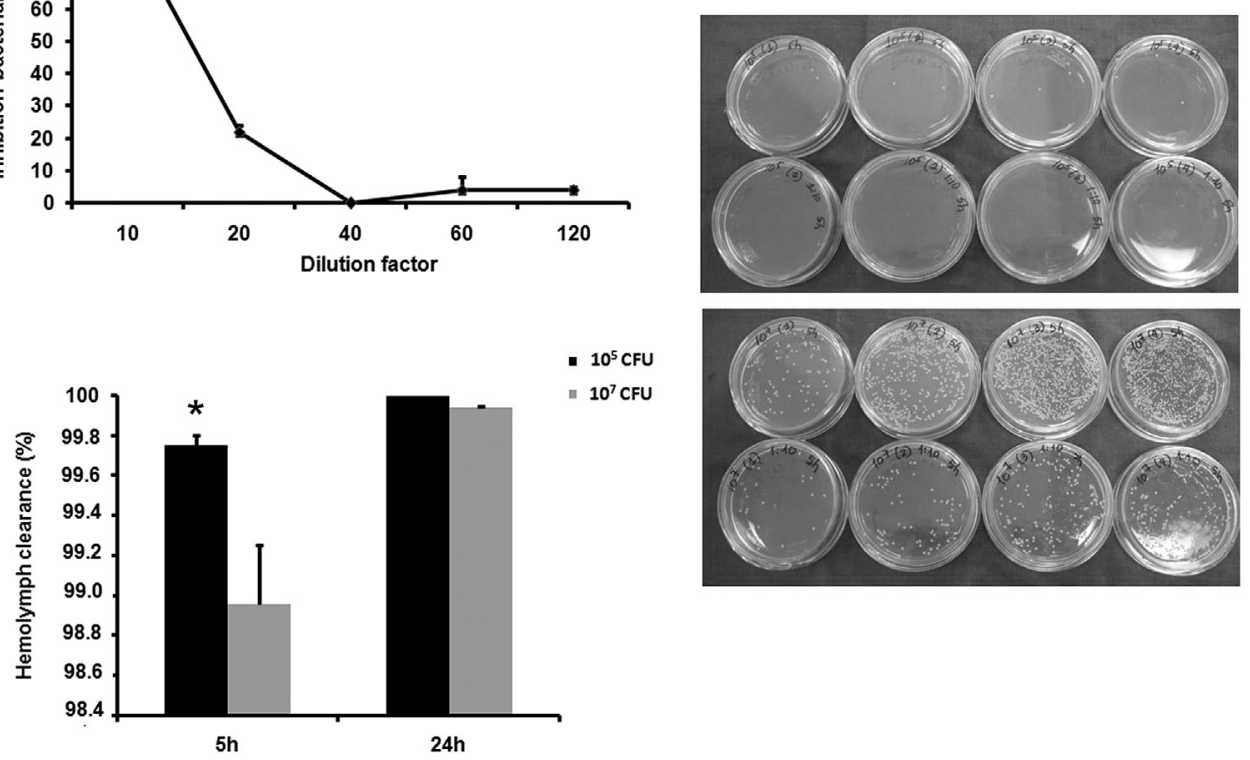

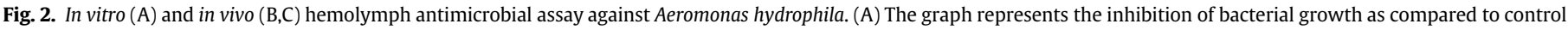

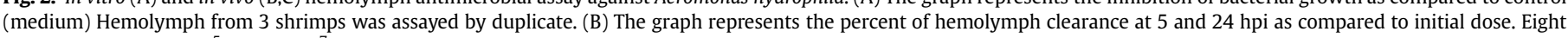

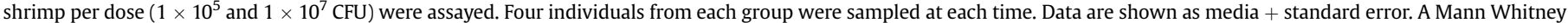

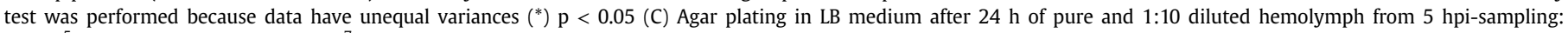
$1 \times 10^{5} \mathrm{CFU}$ (upper panel) and $1 \times 10^{7} \mathrm{CFU}$ (lower panel). 
A

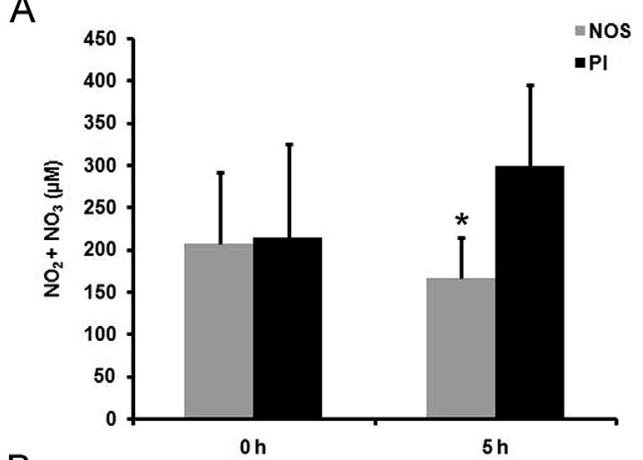

B

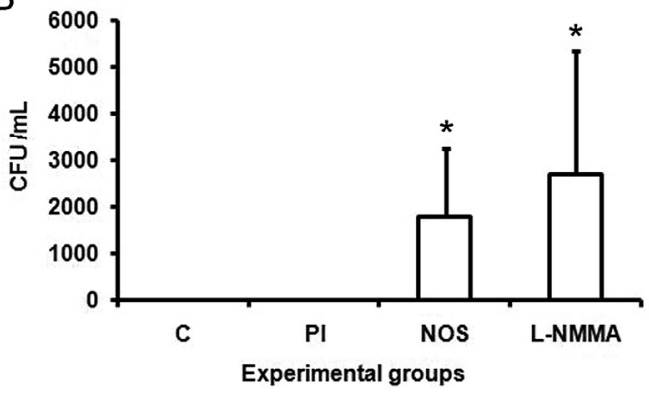

C
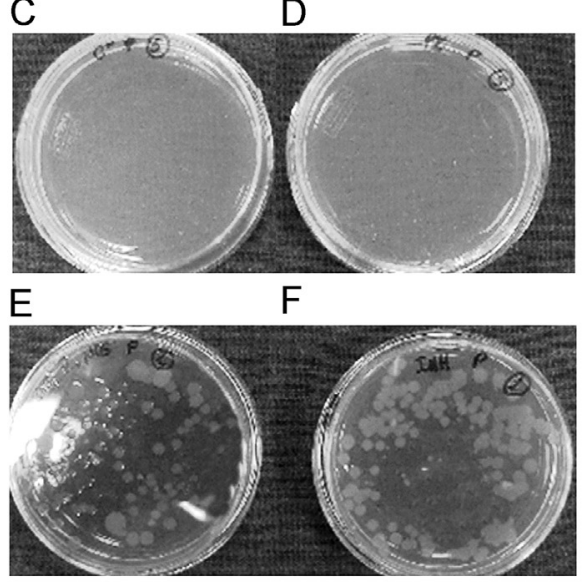

G $\quad H$

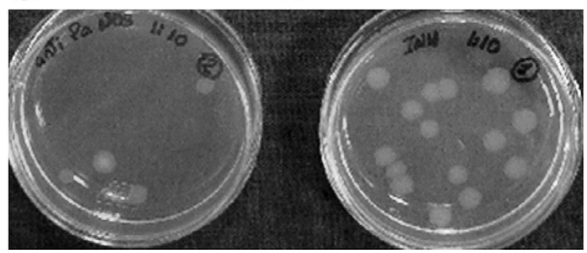

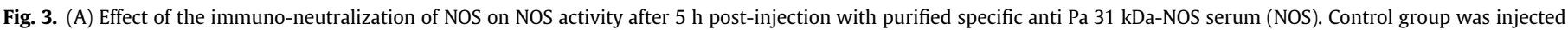

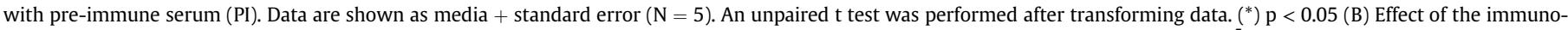

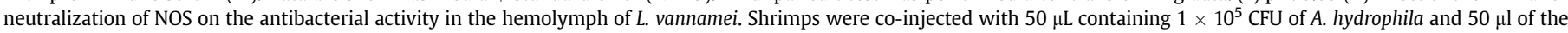

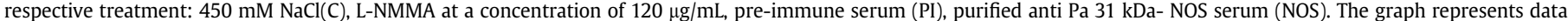

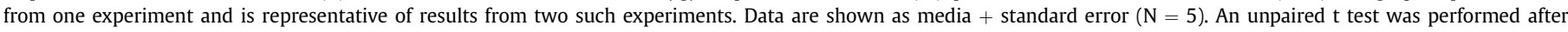

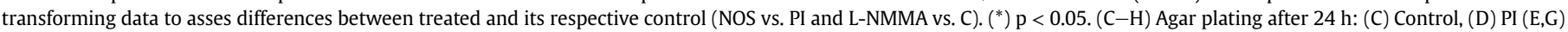
NOS, (F,H) L-NMMA. (C-F) undiluted hemolymph, (G-H) 1:10 diluted hemolymph.

plates with hemolymph from shrimps injected with the inhibitor of NOS (L-NMMA) or the anti-Pa 31 kDa-NOS antibody showed bacterial growth depending on the dilution of the hemolymph (Fig $3 \mathrm{~B}$, E-H). The fact that we didn't detect any bacteria growth for both control groups after $24 \mathrm{~h}$ indicated that the hemolymph antibacterial activity wasn't affected by any component of the rabbit plasma.

L-NMMA is known as a very well established cell-permeable competitive NOS inhibitor in mammals, used to evaluate the role of the L-arginine: nitric oxide pathway (Ki values are $700 \mathrm{nM}$, $3.9 \mu \mathrm{M}$ and $650 \mathrm{nM}$ for eNOS, iNOS and nNOS, respectively). However, L-NMMA selective activity has also been demonstrated in invertebrates. For example, E. coli LPS increased the number of bacteria found around the immunocytes of the molluscan Viviparus ater, but this effect was selectively prevented by the addition of LNMMA, suggesting that this bacterial clumping is caused by the cells liberating NO [25]. Also, the nitrite/nitrate-generating activity in homogenates of crayfish (Procambarus clarkii) hemocytes was inhibited by adding L-NMMA to the incubation [26].

In addition, other mammalian NOS inhibitors have been used to study NOS in invertebrates. In cultured primary shrimp hepatopancreatic cells, coincubation with L-NAME (L-NG-Nitroarginine methyl ester) ablated $V$. harveyi induced-NO production in a dose dependent manner [10]. These authors found that this NOS inhibitor enhanced the survival rate of infecting $V$. harveyi in cultured primary L. vannamei hepatopancreatic cells after $24 \mathrm{~h}$ of exposure, suggesting that NO from inducibly expressed NOS could be important for clearing invading $V$. harveyi in shrimp hepatopancreatic cells. V. harveyi is also a Gram negative bacterium and a serious pathogen to marine fish and invertebrates.

It is important to consider that the $P$. argus NOS fragment selected to generate the polyclonal antibody [5] has $84 \%$ identity with a similar fragment in the protein sequence from $L$. vannamei. Besides, the identity percent ranges from 41 to $84 \%$ with arthropods sequences, being the highest identity percents with crustaceans. No similarities were found with other proteins. Thus, cross-reactivity with a protein with the same function seems to be unlikely.

The induction of NOS gene expression in crustacean by bacteria or bacterial components has been previously studied in vitro $[4,10]$ and in vivo [5,8-10]. Therefore, we suppose the injection of $A$. hydrophila probably induced the expression of NOS in the shrimps of the present study. If it was the case, the doses of L-NMMA and anti-Pa 31 kDa-NOS antibody were a sufficient amount to neutralize the circulating NOS before and after the induction, significant enough to cause the decrease of the antibacterial activity of the hemolymph. The antimicrobial actions of NOS have been attributed to the nitric oxide radical itself, and to various reaction products referred to as reactive nitrogen intermediates, such as NONOates, S-nitrosothiols, peroxynitrite, nitrite and nitrous acid thatcan react with structural elements, components of the replication machinery, nucleic acids, metabolic enzymes, or with virulence-associated molecules. For example, the peroxynitrites, produced by the reaction between reactive oxygen intermediates and NO radical are capable of oxidizing SH groups, lipids and DNA, and causing nitration of tyrosine residues of proteins of the microorganism [27]. Control of pathogens by NOS-derived NO can imply their death or the reduction of the microbial metabolic activity causing sufficient impairment of pathogen proliferation in vivo to allow clinical resolution of the disease by the immune response (for review, see Ref. [28]).

In this work, we localized for first time NOS in shrimps hemocytes using a polyclonal antibody against $P$. argus NOS by western blotting and immunofluorescence. Additionally, we demonstrated that this antibody was able to reduce NOS activity in vivo. 
Afterward, we also showed that the strong antibacterial activity of the hemolymph of shrimps against Gram negative bacteria is affected because of the administration of this polyclonal antibody or a chemical NOS inhibitor (L-NMMA). These findings contribute to the knowledge about the role of NOS in the immune response of crustaceans, specifically shrimps, to Gram negative bacteria. Moreover, this study would encourage further investigation on the regulation of NOS activity in invertebrates, its expression during infections and the possibility to use as a tool for monitoring shrimp health.

\section{References}

[1] C.H. Bogdan, Nitric oxide and the regulation of gene expression, Trends Cell. Biol 11 (2) (2001) 66-75.

[2] A. Pautz, J. Art, S. Hahn, S. Nowag, C. Voss, H. Kleinert, Regulation of the expression of inducible nitric oxide synthase, Nitric Oxide 23 (2010) 75-93.

[3] C.M. Gonzalez-Domenech, R. Muñoz-Chapuli, Molecular evolution of nitric oxide synthases in metazoans, Comp Biochem. Physiol Part D 5 (2010) 295-301.

[4] T. Rodriguez-Ramos, Y. Carpio, J. Bolivar, G. Espinosa, J. Hernandez-Lopez, T. Gollas-Galvan, et al., An inducible nitric oxide synthase (NOS) is expressed in hemocytes of the spiny lobster Panulirus argus: cloning, characterization and expression analysis, Fish Shellfish Immunol 29 (2010) 469-479.

[5] T. Rodriguez-Ramos, Y. Carpio, L. Ramos, T. Pons, O. Farnos, C. Iglesias, et al. New aspects concerning to the characterization and the relationship with the immune response in vivo of the spiny lobster Panulirus argus nitric oxide synthase, Nitric Oxide Biol Chemistry/Official J Nitric Oxide Soc 25 (2011) 396-406.

[6] C.H. Wu, V.S. Siva, Y.L. Song, An evolutionarily ancient NO synthase (NOS) in shrimp, Fish Shellfish Immun 35 (2013) 1483-1500.

[7] J.A. Xian, Y.T. Miao, B. Li, H. Guo, A.L. Wang, Apoptosis of tiger shrimp (Penaeus monodon) haemocytes induced by Escherichia coli lipopolysaccharide, Comp Biochem. Physiol A 164 (2013) 301-306.

[8] M. Inada, T. Mekata, R. Sudhakaran, S. Okugawa, T. Kono, A.M. El Asely, et al. Molecular cloning and characterization of the nitric oxide synthase gene from kuruma shrimp, Marsupenaeus japonicus, Fish Shellfish Immunol 28 (2010) 701-711.

[9] C.L. Yao, P.F. Ji, Z.Y. Wang, F.H. Li, J.H. Xiang, Molecular cloning and expression of NOS in shrimp, Litopenaeus vannamei, Fish Shellfish Immunol 28 (2010) 453-460.

[10] T. Chen, N.K. Wong, X. Jiang, X. Luo, L. Zhang, D. Yang, et al., Nitric oxide as an antimicrobial molecule against Vibrio harveyi infection in the hepatopancreas of Pacific white shrimp, Litopenaeus vannamei.Fish Shell Immunol 42 (2015) $114-120$.

[11] K. Söderhäll, V.J. Smith, Separation of the hemocyte populations of Carcinus maenus and other marine decapods, and prophenoloxidase distribution, Dev
Comp Immunol 7 (1983) 229-239,

[12] L Gómez, R. Hernández, N. Ibarra, R. Valdés, Y. Campos, A. Tamayo, et al., Comparison of different ligand densities for the manufacture of CB.Hep-1 immunosorbents, J Biochem. Methods 52 (2002) 151-159.

[13] M. Wilchek, T. Miron, J. Kohn, Affinity chromatography, Methods Enzymol 104 (1984) 3-55.

[14] J. Porath, R. Axén, S. Ernback, Chemical coupling of proteins to agarose, Nature 215 (1967) $1491-1492$.

[15] J. Kohn, M. Wilchek, A colorimetric method for monitoring activation of sepharose by cyanogen bromide, Biochem. Res Commun 84 (1) (1978) 7-14.

[16] H.W. Kim, L.A. Batista, J.L. Hoppes, K.J. Lee, D.L. Mykles, A crustacean nitric oxide synthase expressed in nerve ganglia, Y-organ, gill and gonad of the tropical land crab, Gecarcinus Lateralis. J Exp Biol 207 (16) (2004) 2845-2857.

[17] A.A. McDonald, E.S. Chang, D.L. Mykles, Cloning of a nitric oxide synthase fromgreen shore crab, Carcinus maenas: a comparative study of the effects of eyestalk ablation on expression in the molting glands (Y-organs) of C. maenas, and blackback land crab, Gecarcinus lateralis, Comp Biochem. Physiol Part A 158 (2011) 150-162.

[18] J. Hernández-López, T. Gollas-Galván, F. Vargas-Albores, Activation of the proPO system of the brown shrimp (Penaeus californiensis Holmes), Comp Biochem. Physiol 113C (1996) 61-66.

[19] T. Rodríguez-Ramos, E. Espinosa, J. Hernández-López, T. Gollas-Galván, J. Marrero, Y. Borrell, et al., Effects of Echerichia coli lipopolysaccharides and dissolved ammonia on immune response in southern white shrimp Litopenaeus schmitti, Aquaculture 274 (2008) 118-125.

[20] E.J. Noga, T.A. Arroll, R.A. Bullis, L. Khoo, Antibacterial activity in hemolymph of white shrimp, Penaeus setiferus, J Mar Biotechnol 4 (1996) 181-184.

[21] J.R.S. Chisholm, V.J. Smith, Comparison of antibacterial activity in the hemocytes of different crustacean species, Comp Biochem. Physiol A 110 (1995) $39-45$.

[22] K. Sritunyalucksana, P. Sithisarn, B. Withayachumnarnkul, T.W. Flegel, Activation of prophenoloxidase, agglutinin and antibacterial activity in hemolymph of the black tiger prawn, Penaeus monodon, by immunostimulants, Fish Shellish Immunol 9 (1999) 21-30.

[23] T. Haug, A.K. Kjuul, K. Stenvarg, E. Sandsdalen, B. Styrvold, Antibacterial activity in four marine crustacean decapods, Fish Shellfish Immunol 12 (2002) 371-385.

[24] W.S. Fredrick, S. Ravichandran, Hemolymph proteins in marine crustaceans, Asian Pac J Trop Biomed 2 (6) (2012) 496-502.

[25] E. Ottaviani, L.R. Paeman, P. Cadet, G.B. Stefano, Evidence for nitric oxide production and utilization as a bacteriocidal agent by invertebrate immunocytes, Eur J Pharmacol 248 (4) (1993; Dec 1) 319-324.

[26] Yeh FCh, S.-H. Wu, Ch-Y. Lai, Ch-Y. Lee, Demonstration of nitric oxide synthase activity in crustacean hemocytes and anti-microbial activity of hemocytederived nitric oxide, Comp Bioch Physiol. Part B 144 (2006) 11-17.

[27] D. Chakravortty, M. Hensel, Inducible nitric oxide synthase and control of intracellular bacterial pathogens, Microbes Infect. 5 (2003) 621-627.

[28] C.H. Bogdan, Nitric oxide synthase in innate and adaptive immunity: an update, Trends Immunol 36 (3) (2015) 161-178. 